\title{
EFEKTIFITAS KEPEMIMPINAN DALAM MEMOTIVASI PUSTAKAWAN DI LINGKUNGAN PERPUSTAKAAN
}

\author{
Syamsuddin \\ e_mail: syam.wid@gmail.com \\ FAKULTAS SYARI'AH DAN HUKUM \\ UIN SULTHAN THAHA SAIFUDDIN JAMBI
}

\begin{abstract}
ABSTRAK
Tulisan ini bertujuan untuk mengetahui bagaimana peran pemimpin dalam memotivasi pusakawan sebagai pegawai professional di lingkungan perpustakaan.Tulisan ini memfokuskan pada bagaimana pola kepemipinan pemimpin dalam motivasi pustakawan terkait dengan kegiatan kepustakawanan, dan apa saja hambatan-hambatan yang dihadapi dalam memotivasi pustakawan.

Kata Kunci: Efektivitas Kepemimpinan, Motivasi, Kepemimpinan
\end{abstract}

\section{A. PENDAHULUAN}

Urgensi motivasi dalam upaya menumbuh kembangkan budaya atau semangat kerja bagi seseorang khususnya di lingkungan oragnisasi atau perusahaan pada dasarnya merupakan manifestasi untuk mencapai kebahagiaan baik kepada individu yang bersangkutan maupun kepada lembaga.Motivasi muncul sebagai konsekuensi logis dari beragamnya prilaku (behaviour) individu dalam suatu organisasi atau lembaga yang hendak mewujudkan visi dan misinya.Karena itulah, motiviasi menjadi elemen penting dalam berbagai kajian ilmu khususnya pada ilmu manajemen.Para pakar ilmu manajemen bersepakat bahwa motivasi harus dijadikan sebagai bagian penting dari kajian ilmu manajemen khususnya pada manajemen sumber daya manusia (human resources management).

Berdasarkan prolog tersebut, maka peran pemimpin dalam memotivasi pegawai menjadi keharusan sebab inti dari suatu motivasi adalah bagaimana mendorong individu untuk berprilaku positif dan sadar akan tugas dan tanggung jawabnya dalam suatu organisasi atau lembaga.

\section{B. PEMBAHASAN}

\section{A. Pengertian Efektifitas dan Motivasi}

\section{Pengertian Efektifitas}

Menurut Kamus Besar Bahasa Indonesia, kata efektif mempunyai arti efek, pengaruh, akibat atau dapat membawa hasil. Efektivitas adalah keaktifan, daya guna, adanya kesesuaian dalam suatu kegiatan orang yang melaksanakan tugas dengan sasaran yang dituju. Efektivitas pada dasarnya menunjukkan pada taraf tercapainya hasil, sering atau senantiasa dikaitkan 
dengan pengertian efisien, meskipun sebenarnya ada perbedaan diantara keduanya. Efektivitas menekankan pada hasil yang dicapai, sedangkan efisiensi lebih melihat pada bagaiman cara mencapai hasil yang dicapai itu dengan membandingkan antara input dan outputnya.Efektivitas menunjukkan keberhasilan dari segi tercapai tidaknya sasaran yang telah ditetapkan.Jika hasil kegiatan semakin mendekati sasaran, berarti makin tinggi efektivitasnya.Sejalan dengan pendapat tersebut, Abdurahmat dalam Othenk (2008: 7), efektivitas adalah pemanfaatan sumber daya, sarana dan prasarana dalam jumlah tertentu yang secara sadar ditetapkan sebelumnya untuk menghasilkan sejumlah pekerjaan tepat pada waktunya.Dapat disimpulkan bahwa efektivitas berkaitan dengan terlaksananya semua tugas pokok, tercapainya tujuan, ketepatan waktu, dan partisipasi aktif dari anggota serta merupakan keterkaitan antara tujuan dan hasil yang dinyatakan, dan menunjukan derajat kesesuaian antara tujuan yang dinyatakan dengan hasil yang dicapai.

Aspek-aspek efektivitas berdasarkan pendapat Muasaroh (2010: 13), efektivitas dapat dijelaskan bahwa efektivitas suatu program dapat dilihat dari aspek-aspek antara lain: (1) Aspek tugas atau fungsi, yaitu lembaga dikatakan efektivitas jika melaksanakan tugas atau fungsinya, begitu juga suatu program pembelajaran akan efektiv jika tugas dan fungsinya dapat dilaksanakan dengan baik dan peserta didik belajar dengan baik; (2) Aspek rencana atau program, yang dimaksud dengan rencana atau program disini adalah rencana pembelajaran yang terprogram, jika seluruh rencana dapat dilaksanakan maka rencana atau progarm dikatakan efektif; (3) Aspek ketentuan dan peraturan, efektivitas suatu program juga dapat dilihat dari berfungsi atau tidaknya aturan yang telah dibuat dalam rangka menjaga berlangsungnya proses kegiatannya. Aspek ini mencakup aturan-aturan baik yang berhubungan dengan guru maupun yang berhubungan dengan peserta didik, jika aturan ini dilaksanakan dengan baik berarti ketentuan atau aturan telah berlaku secara efektif; dan (4) Aspek tujuan atau kondisi ideal, suatu program kegiatan dikatakan efektif dari sudut hasil jika tujuan atau kondisi ideal program tersebut dapat dicapai. Penilaian aspek ini dapat dilihat dari prestasi yang dicapai oleh peserta didik.

\section{Pengertian Motivasi}

Secara etimologi kata motivasi berasal dari bahasa Inggris, yaitu "motivation", yang artinya "daya batin" atau “dorongan”.Sehingga pengertian motivasi adalah segala sesuatu yang mendorong atau menggerakkan seseorang untuk bertindak melakukan sesuatu dengan tujuan tertentu.

Weiner menyebutkan bahwa motivasi adalah kondisi internal yang membangkitkan seseorang untuk bertindak, mendorong individu mencapai tujuan tertentu, dan membuat 
individu tetap tertarik dalam kegiatan tertentu.Menurut Uno, arti motivasi adalah dorongan internal dan eksternal dalam diri seseorang yang diindikasikan dengan adanya; hasrat dan minat; dorongan dan kebutuhan; harapan dan cita-cita; penghargaan dan penghormatan.Menurut G. R. Terry pengertian motivasi adalah sebuah keinginan yang ada pada diri seseorang yang merangsangnya untuk melakukan berbagai tindakan.

\section{Faktor-Faktor Motivasi}

Proses psikologis di dalam diri seseorang yang menimbulkan motivasi dipengaruhi oleh berbagai faktor. Adapun faktor-faktor motivasi adalah sebagai berikut :

\section{a. Faktor Internal (Intern)}

Faktor internal adalah faktor motivasi yang berasal dari dalam diri seseorang. Motivasi internal timbul karena adanya keinginan individu untuk memiliki prestasi dan tanggungjawab di dalam hidupnya.Beberapa hal yang termasuk dalam faktor internal adalah:

- Harga diri dan Prestasi, yaitu motivasi di dalam diri seseorang untuk mengembangkan kreativitas dan mengerahkan energi untuk mencapai prestasi yang meningkatkan harga dirinya.

- Kebutuhan, setiap individu memiliki kebutuhan di dalam hidupnya sehingga orang tersebut menjadi termotivasi untuk melakukan sesuatu untuk memenuhi kebutuhan hidupnya.

- Harapan, yaitu sesuatu yang ingin dicapai seseorang di masa mendatang yang mempengaruhi sikap dan perasaan subjektif orang tersebut.

- Tanggungjawab, yaitu motivasi di dalam diri seseorang agar bekerja dengan baik dan hati-hati untuk menghasilkan sesuatu yang berkualitas.

- Kepuasan kerja, yaitu motivasi dalam diri seseorang karena dapat melakukan suatu pekerjaan tertentu.

\section{b. Faktor Eksternal (Ekstern)}

Faktor eksternal adalah faktor motivasi yang berasal dari luar diri seseorang.Motivasi eksternal timbul karena adanya peran dari luar, misalnya organisai, yang turut menentukan perilaku seseorang dalam kehidupannya.Beberapa hal yang termasuk dalam faktor eksternal adalah:

- Jenis dan sifat pekerjaan, yaitu dorongan di dalam diri seseorang untuk bekerja pada jenis dan sifat pekerjaan tertentu. Kondisi ini juga dipengaruhi oleh besar imbalan yang didapatkan pada pekerjaan tersebut.

- Kelompok kerja, yaitu organisasi dimana seseorang bekerja untuk mendapatkan penghasilan bagi kebutuhan hidupnya.

- Kondisi kerja, yaitu keadaan dimana seseorang bekerja sesuai dengan harapannya (kondusif) sehingga dapat bekerja dengan baik.

- Keamanan dan keselamatan kerja, yaitu perlindungan yang diberikan oleh organisasi terhadap jaminan kemanan dan keselamatan seseorang dalam bekerja. 
- Hubungan interpersonal, yaitu hubungan antara teman sejawat, dengan atasan, dan dengan bawahan. Dalam hal ini, setiap orang ingin dihargai dan menghargai dalam organisasi sehingga tercipta suasana kerja yang harmonis.

\section{B. Efektifitas Pemimpin Dalam Memotivasi Pegawai di Lingkungan Kerja}

Keberadaan pemimpin baik di lingkungan perusahaan swasta maupun lembaga pemerintah memiliki peran yang sangat strategis dalam upaya menumbuhkembangkan lingkungan kerja yang dinamis bagi para pegawai, namun demikian pemimpin juga membutuhkan dukungan dari pegawai agar mobilisasi lembaga atau perusahaan berjalan sesuai dengan harapan. Namun demikian, harus disadari bahwa setiap individu yang terlibat dalam kegiatan di lembaga atau perusahaan memiliki karakter (character) dan prilaku (behavior) yang berbeda-beda.Dibutuhkan kemampuan manajerial yang mumpuni oleh pemimpin untuk memahami perbedaan yang dimiliki oleh setiap pegawai yang ada.

Salah satu elemen yang paling penting dalam upaya menumbuh kembangkan semangat pegawai dalam menunaikan tugasnya adalah motivasi.Motivasi berasal dari bahasa Latin "movere", yang berarti menggerakkan. ${ }^{1}$ Motivasi adalah kondisi internal yang membangkitkan kita untuk bertindak, mendorong kita mencapai tujuan tertentu, dan membuat kita tetap tertarik dalam kegiatan tertentu. ${ }^{2}$ sebagai dorongan internal dan eksternal dalam diri seseorang yang diindikasikan dengan adanya; hasrat dan minat; dorongan dan kebutuhan; harapan dan cita-cita; penghargaan dan penghormatan. Motivasi adalah sesuatu apa yang membuat seseorang bertindak. ${ }^{3}$ Sementara Campbell \& Pritchard menyebutkan bahwa

"Motivation has to do with a set of independent / dependent variable relationship that explain the direction, and persistence of individual's behavior, holding constant the effects of attitude, skill, and understanding of the task, and the constraints operating in the environment. ${ }^{4}$

Berdasarkan pengertian ini dapat dipahami bahwa memotivasi seseorang atau pegawai yang ada di lingkungan perusahaan atau lembaga menjadi tanggung jawab moral para pemimpin. David McClelland memperkenalkan tiga jenis motivasi yang diindikasikan

\footnotetext{
${ }^{1}$ John M Echols and Hasan Shadily.Kamus Bahasa Inggris-Indonesia. (Jakarta : Gramedia, 2012). Hal. 387

${ }^{2}$ Weiner, Bernard. Human Motivation. ( Holt, Rinehart, and Winston. 1972)

${ }^{3}$ Robbins. Stephen. P; Perilaku Organisasi.(Jakarta : PT. Indeks Kelompok Gramedia, 2008), p.

${ }^{4}$ Richard M. Steers, Lyman W. Porter.Motivation and work behavior. (London : McGraw Hill, 1991) p. 5
} 
cukup efektif dalam membangkitkan semangat pegawai dalam menunaikan tugasnya, diantaranya ; 1) motivasi untuk berprestasi $(n-A C H)$; 2) motivasi untuk berkuasa (n-pow); dan 3) motivasi untuk berafiliasi/bersahabat ( $n$-affil).

Berdasarkan konsep David McClelland di atas bahwa seseorang akan bekerja memiliki hasrat untuk mencapai keinginannya untuk berprestasi agar dia memperoleh pengakuan akan eksistensinya baik di lingkungan kerjanya maupun dilingkungan sosialnya. Untuk mencapai prestasi sebagaimana yang diharapkan oleh pegawai maka bentuk motivasi yang dilakukan oleh pimpinan dapat berupa ;Pertama, memberikan reward kepada pegawai sesuai dengan prestasi kerja yang dihasilkan. Menurut Doglas McGregor dalam teori Y meenyebutkan reward dapat diberikan kepada pegawai jika pegawai mampu menyelesaikan tugas dan masalah secara efektif dan efisien. ${ }^{5}$ Seorang pegawai yang mampu menyelesaikan tugas dengan professional umumnya didasarkan pada kesadaran akan pentingnya tanggung jawab yang menyangkut kepentingan orang banyak. Selanjutnya dikatakan oleh Douglas bahwa manajemen dengan pendekatan $\mathrm{X}$ akan diberikan kepada pegawai yang berprestasi baik, dan menghukum bagi pegawai yang tidak berrestasi. Sedangkan bagi pegawai yang bertipe teori Y, manajemen akan memberikan motivasi dengan melakukan promosi jabatan dan pengembangan karir yang lebih baik bagi pegawai yang bersangkutan.

Kedua, pola komunikasi yang lebih komunikatif.Pola ini dimaksudkan agar pegawai yang ada di lingkungan lembaga atau perusahaan merasa nyaman dan merasa memiliki terhadap lembaga. Maslow menilai bahwa pola komunikasi merupakan metode yang dapat mendorong bagi pegawai akan keberadaannya sangat dibutuhkan oleh perusahaan dan orang lain. Bentuk akan pemenuhan kebutuhan ini seperti bersahabat, kebutuhan untuk dekat pada perusahaan atau lembaga dan kebutuhan antarpribadi seperti kebutuhan untuk memberi dan menerima perhatian. ${ }^{6}$ Dengan peran seperti ini akan berdampak pada semangat kerja pegawai.

Ketiga, mendorong pegawai untuk menghadapi tantangan.Peran pimpinan dalam hal ini adalah memberikan kepercayaan kepada pegawai mengenai kemampuan mereka dalam menghadapi segala rintangan, pimpinan harus meyakinkan bahwa segala macam bentuk masalah dan tantangan dapat diatasi jika kita harus bekerja secara kolaboratif. Menurut Donald $\mathrm{H}$ McGannon bahwa pegawai membutuhkan dukungan dri pimpinan berupa kebutuhan keamanan, rasa aman, psikologis untuk bekerja secara kolaboratif agar kinerja

${ }^{5}$ Marks A. Thomas.Gurus on Leadership. (London : Thorogood Publishing Ltd, 2006), p. 105

${ }^{6}$ Ibid. Marks A. Thomas. Gurus..., p. 102. Teori ini juga digagas dalam teori motivasi Alderfer (ERG Theory), ada tiga kelompok inti dari kebutuhan ini yakni : Kebutuhan akan keberadaan (existence), Kebutuhan berhubungan/interaksi (relatedness), dan Kebutuhan untuk berkembang (growth need) kebutuhan bersifat tidak bertingkat tapi bersifat kontinum, jadi kebutuhan bias muncul secara bersama-sama. 
(perform) mereka menjadi lebih baik ${ }^{7}$. Acapkali pegawai takut dan khawatir terhadap berbagai kemungkinan-kemungkinan yang akan dihadapi oleh dirinya maupun lembaga sehingga membuat pegawai tidak maksimal dalam bekerja, maka disinilah peran pimpinan untuk memotivasi pegawai agar rasa kepercayaannya bangkit. Pimpinan tidak bias melakukan pembiaran dengan kesibukan dirinya, hanya menerima laporan dari bawahaannya maupun hanya meninginkan kemajuan atau keuntungan semata tanpa melakukan pendekatan social dengan pegawainya.

\section{Efektifitas Pemimpin dalam Memberdayakan Pegawai}

Pemberdayaan merupakan suatu proses yang pada hakikatnya bertujuan untuk terwujudnya "perubahan".Pegawai adalah salah satu sumber daya terpenting bagi setiap perusahaan untuk mencapai tujuannya.Berbeda dengan sumber-sumber daya lainnya, pegawai adalah sumber daya yang sangat spesifik karena mempunyai perilaku dan perasaan serta memiliki akal dan tujuan pribadi masing-masing.Karenanya, mengelola sumber daya manusia (pegawai) menjadi salah satu hal yang sangat penting dalam menjalankan mewujudkan visi dan misi perusahaan atau lembaga.

Memberdayakan pegawai merupakan proses kegiatan yang dilakukan oleh pemimpin di lingkungan kerja dengan maksud agar pegawai mampu menyelsaikan tugas-tugasnya secara professional, dan mengembangkan potensi, bakat dan kemampuan agar pegawai mampu berkompetisi. Salah satu tugas elemen penting dalam mengembangkan organisasi oleh pemimpin adalah memberdayakan sumber daya manusia pegawai.Seorang pemimpin yang menghadapi karakter pegawai yang berbeda-beda namun secara structural memiliki potensi untuk membantu dalam mengembangkan organisasi kea rah yang lebih positif.McGregor menyebutkan bahwa seorang pemimpin ketika menghadapi pegawai yang berprilaku malas maka hendaknya menerapkan pola kepemimpinan atau manajemen otoritas. Sharafat khan dalam Syafrizal Helmi, menawarkan suatu model pemberdayaan pustakawan, yaitu antara lain :

1) Desire. Tahap pertama dalam model empowerment adalah adanya keinginan dari manajemen untuk mendelegasikan dan melibatkan pekerja.

2) Rust.Setelah adanya keinginan dari manajemen untuk melakukan pemberdayaan, langkah selanjutnya adalah membangun kepercayaan antar manajemen dan karyawan. Adanya saling percaya antara anggota organisasi akan tercipta kondisi yang baik untuk pertukaran informasi dan saran tanpa adanya rasa takut.

\footnotetext{
${ }^{7}$ John Adair. Leadership and Motivation. (London : Talbot Adair Press, 2006), p. 9
} 
3) Confident. Langkah selanjutnya setelah adanya saling percaya adalah menimbulkan rasa percaya diri karyawan dengan menghargai terhadap kemampuan yang dimiliki oleh karyawan.

4) Credibility. Langkah keempat menjaga kredibilitas dengan penghargaan dan mengembangkan lingkungan kerja yang mendorong kompetisi yang sehat sehingga tercipta organisasi yang memiliki performance yang tinggi.

5) AccountibilityTahap dalam proses pemberdayaan selanjutnya adalah pertanggung jawaban karyawan pada wewenang yang diberikan. Dengan menetapkan secara konsisten dan jelas tentang peran, standar dan tujuan tentang penilaian terhadap kinerja karyawan, tahap ini sebagai sarana evaluasi terhadap kinerja karyawan dalam penyelesaian dan tanggung jawab terhadap wewenang yang diberikan

6) Communication. Langkah terakhir adalah adanya komunikasi yang terbuka untuk menciptakan saling memahami antar karyawan dan manajemen. Keterbukaan ini dapat diwujudkan dengan adanya kritik dan saran terhadap hasil dan prestasi yang dilakukan pekerja. Hal yang termasuk dalam communication

Adapun efektifitas kepemimpinan yang harus dimiliki oleh pemimpin dalam memberdayakan pegawai adalah :

\section{Komitmen Terhadap Program Perpustakaan}

Melakukan sistim manajemen yang terencana agar proses kegiatan yang dilakukan dapat tercapai. Menueurt Bernard M. Bass dan Ronald E. Riggio bahwa kepmimpinan yang efektif dalam memberdyakan pegawai adalah seorang pemimpin yang harus memiliki kepemimpinan yang tranformasional yang mencakup dalam berbagai bidang diantaranya ; penilaian, komitmen, loyalitas, kepuasan, kebijakan sampai pada kemampuan untuk memprediksi kemungkinan-kemungkinan tantangan yang akan dihadapi oleh lembaga atau perusahaan ke depan (visioner). ${ }^{8}$

Menjadi pimpinan yang dapat jadi panutan merupakan salah satu upaya untuk menjadikan lembaga yang lebih berwibawa, seorang pimpinan yang dapat jadi panutan akan mampu membuat keputusan, memecahkan masalah, memiliki kebijakan yang selalu terbuka, tahu bagaimana mendelegasikan, dan memberikan umpan balik yang baik. Orang-orang akan termotivasi ketika mereka mempercayai pemimpin mereka.

Dengan demikian bahwa melibatkan (engage) pustakawan berarti bahwa orang -orang menikmati pekerjaan mereka dan merasa puas dengan kondisi kerja mereka, berkontribusi

\footnotetext{
${ }^{8}$ Menueurt Bernard M. Bass dan Ronald E. Riggio. Transformational leadership. (London : Lawrence Erlbum Associates. Publisher, 2006), p. 19-47.
} 
secara antusias untuk memenuhi tujuan tim dan organisasi, dan merasakan kesan kebahagiaan dan komitmen pada organisasi.

Dengan demikian bahwa pemimpin yang berkitmen terhadap program yang telah ditetapkan akan berdampak pada keseriusan pustakawan dalam menjalankan tugasnya. Pustakawan lebih terfokus dan tidak menimbulkan fikiran yang ambigu.Pustakawan seringkali menghadapi ketidak pastian dlam menjalankan tugasnya sebab pimpinan seringkali berubah-ubah dalam menjalankan programnya.

\section{Membangun Budaya Kerjasama (Team Work)}

Konsep kerjama atau sering disebut dengan team work dalam suatu institusi perpustakaan merupakan suatu konsep yang dapat memberikan efektifitas dan efisiensi pekerjaan. Sebagai lembaga yang berorientasi pada jasa layanan informasi, perpustakaan dihadapkan sejumlah pekerjaan dan layanan yang harus dilakoni oleh para pustakawan yakni mulai dari pekerjaan kepustakawanan sampai pada bimbingan kepada pemustaka (user). Di sisi lain tuntutan para pustakawan unstuck senantiasa menunaikan tugasnya secara professional maka mau tidak mau harus dilakukan secara kolaboratif agar tidak menimbulkan penilaian negative dari para pemustaka.

\section{Membangun Komunikasi Transparan}

Banyak perusahaan yang menerapkan komunikasi berdasarkan hierarki top-down.Untuk para eksekutif, sistem ini mungkin terasa natural.Tapi karyawan yang berada di bawah bisa merasa bahwa mereka tidak punya andil dalam menentukan keberhasilan perusahaan. Meski para pimpinan punya lebih banyak pengalaman, bukan berarti mereka bebas mengabaikan feedback dari pekerja-pekerja di garis depan.

Semua perusahaan harus menyediakan solusi supaya buah pikiran karyawan bisa didengar.Pemberdayaan karyawan artinya membuat para karyawan merasa bahwa ide mereka dihargai. Berikan imbalan serta feedback, dan terima masukan karyawan, maka komunikasi dan semangat akan semakin tumbuh

\section{Mendorong untuk Meningkatkan Kompetensi dan Profesional}

Banyak kepala perpustakaan yang komplain karena pustakawanannya tidak punya motivasi, tapi tidak melakukan apa pun untuk mengatasinya. Memberdayakan pustakawan artinya menyediakan ruang bagi pustakawan untuk tumbuh.Bahkan hal simpel seperti menanyakan perkembangan karirnya, kompetensi, sertifikasonya dan menyemangati mereka mencapai tujuan itu bisa membuat pustakawan merasa lebih berarti.

Bantulah pustakawanmenyusun rencana perkembangan untuk mengembangkan karirnya dan tawarkan imbalan atas perkembangan itu. Ini akan membuat para pustakawan lebih 
betah, kemudian ilmu baru yang mereka dapat bisa mereka aplikasikan dalam perpustakaan. Yang terpenting, karyawan jadi merasa bahwa mereka bisa menentukan seperti apa masa depan profesional mereka.

\section{Kesimpulan}

Dari uraian yang telah dijelaskan dapat ditarik kesimpulan bahwapara pegawai pada dasarnya akan mampu melakukan pekerjaan dan ingin mencapai hasil maksimal dalam pekerjaannya. Untuk pencapaian perwujudan kinerja tersebut, dibutuhkan suatu dorongan untuk memunculkan kemauan dan semangat kerja, yaitu dengan adanya motivasi. Motivasi berfungsi untuk merangsang kemampuan para pegawai agar terciptanya hasil kinerja maksimal.Dan tugas pimpinan memiliki peran yang sangat strategis dalam pengupayaan hasil kinerja tersebut. Yaitu dengan memberdayakan para pegawai melalui kepemimpinan transformasional dalam berbagai lini. Kepemimpinan ini dimaksudkan untuk mendorong para pegawai untuk lebih mengembangkan karirnya.

\section{DAFTAR PUSTAKA}

Adair, John.2006.Leadership and Motivation. London : Talbot Adair Press.

Bass, Bernard M. dan Ronald E. Riggio.2006. Transformational leadership. London : Lawrence Erlbum Associates. Publisher.

Echols, John M and Hasan Shadily.2012. Kamus Bahasa Inggris-Indonesia.Jakarta : Gramedia.

Robbins, Stephen. P. 2008.Perilaku Organisasi.Jakarta : PT. Indeks Kelompok Gramedia,).

Steers, Richard M., dan Lyman W. Porter.1991. Motivation and work behavior.London : McGraw Hill.

Thomas, Marks A.2006.Gurus on Leadership.London :Thorogood Publishing Ltd.

Weiner, Bernard.1972.Human Motivation. ( Holt, Rinehart, and Winston.) 